\title{
Fight for Japanese network
}

Tokyo

As Tokyo is one of the three principal financial centres of the world and growing the world's telecommunications giants are fighting to plug their cables into Japan. But an attempt by Britain's Cable and Wirelss to tap Japan's lucrative international telecommunications market has met with a solid wall of resistance.

Following last year's liberalization of Japan's telecommunications law, a consortium headed by Cable and Wireless and $\mathrm{C}$. Itoh, a major Japanese trading house, declared its intention to set up an international telecommunications company that would break the monopoly held by Kokusai Denshin Denva (KDD).

But Mitsubishi Corporation, Mitsui and Co. and Sumitomo Corporation beat the C. Itoh/Cable and Wireless consortium to establish a feasibility study company, International Telecom Japan (ITJ), in July (see Nature 321, 803; 1986).

Whereas ITJ plans to follow established telecommunications routes - Intelstat satellites and a submarine trans-Pacific cable (TPC-3) due to be laid by KDD and American Telephone and Telegraph in 1988 - the C. Itoh/Cable and Wireless group was expected to link up with Cable and Wireless' global digital highway, a network of submarine and transcontinental optical fibre cables connecting Western Europe, the United States and the Far East. But there has been strong opposition to the $\mathrm{C}$. Itoh/Cable and Wireless plan.

Both the Ministry of Post and Telecommunications and KDD maintain that there is not enough room for a third company, and KDD says there is no need for an extra trans-Pacific submarine cable. But the most conservative estimates of Japan's international telecommunications market forecast a tripling in size to $\mathrm{Y} 600,000 \mathrm{mil}-$ lion ( $£ 2,600$ million) by the mid-1990s.

Taking heed of the ministry's pronouncements, the C. Itoh/Cable and Wireless group approached the major shareholders of ITJ in October and suggested a merger but their offer was turned down. And in mid-November the group formed International Digital Communications Planning Co. (IDC) with Cable and Wireless and C. Itoh the major shareholders. No sooner had staff set up its new office than Japan's minister of Post and Telecommunications, Shunjiro Karasawa, let drop a bombshell. In discussions with British Trade Secretary Paul Channon last week, Karasawa announced that although Cable and Wireless could keep its 20 per cent share in IDC (under Japanese law a foreign company can hold up to 33 per cent of a telecommunications company), the British company would be barred from management decisions "because international communications are relevant to national security in emergency situations" and thus a foreign company could not have an influential voice or power in a "second KDD”.

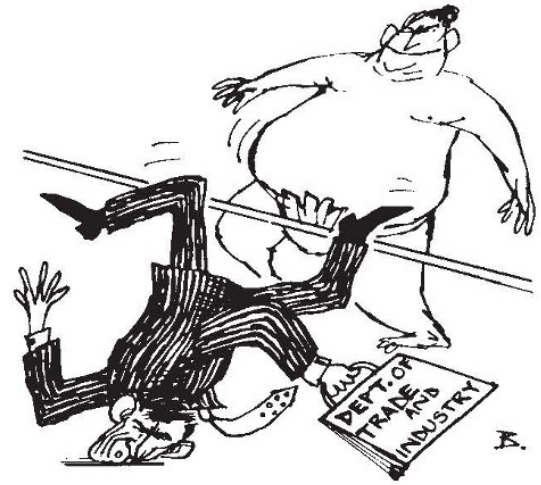

With ITJ expected to apply for a licence from the Ministry of Post and Telecommunications by the end of this month, Karasawa's statement could not have come at a worse time for IDC. And although one of IDC's managing directors insists that the matter is by no means closed, he also emphasized that Cable and Wireless's trans-Pacific cable is only one of the options currently under consideration by his company. David Swinbanks
India creates

\section{biosphere reserve}

\section{Bangalore}

INDIA's first biosphere reserve, patterned after the guidelines in UNESCO's Man and Biosphere Programme, has been inaugurated at Nilgiris in South India, one of twelve biosphere reserves suggested by the Department of Environment (DOE).

It covers an area of $5,520 \mathrm{~km}^{2}$ comprising the famous Silent Valley, a region with 1,500 plant species and virgin forests of western ghats spanning the states of Kerala, Tamil Nadu and Karnataka. The Nilgiris biosphere reserve, classified as a Malabar rain forest, includes $2,020 \mathrm{~km}^{2}$ of minimally disturbed forests in which about 20 tribal groups have been identified.

The reserve is cooperatively managed by the three states under existing state and central legislation on conservation and preservation of forests, wildlife and environment. India has 53 national parks and 247 wildlife sanctuaries covering $100,000 \mathrm{~km}^{2}$.

According to Mr Z.A. Ansari, Union Minister of State for Environment, a comprehensive national conservation strategy is being formulated and steps are being taken to improve the living conditions of tribals in the biosphere reserves.

Radhakrishna Rao

Hepatitis B

\section{Cheap vaccine for wide use?}

\section{Washington}

AN international "task force on Hepatitis B immunization" has announced plans to use a new vaccine costing as little as $\$ 1$ per dose in mass immunization demonstration projects in four developing countries. The nine-member task force, which includes several recognized authorities on the disease, aims to convince governments of countries where the disease is endemic that mass immunization, previously considered too expensive, is economically feasible.

Hepatitis B is most common in Asian countries. It causes 80 per cent of the world's liver cancer, and may be second only to tobacco as a cause of world cancer mortality, acccording to one task force member, Dr Richard Mahoney. As little as a year ago, a dose of vaccine cost $\$ 30$, with three doses needed for a protective course, but Cheil Sugar and Company of Korea has now undertaken to produce it for $\$ 1$.

The Cheil vaccine is of the conventional plasma-derived type and is made under licence from the New York Blood Center. The new process increases by a factor of ten the number of doses obtained for each cubic centimetre of starting plasma, by reducing the number of harsh purification steps and starting with more potent plasma. According to Dr Alfred Prince of the centre, another task force member, the vaccine has been tested in more than 1,000 volunteers for safety and immunogenicity, and long-term effectiveness trials are, at present, under way in several countries.

Demonstration programmes will be mounted in Indonesia, Thailand, Brazil and one African country. Over three years the group expects to vaccinate 1.2 million newborn babies. Vaccinating babies is most effective because those infected before the age of three are far more likely than others to become infectious carriers.

The task force includes members coordinated by a non-profit organization, Program for Appropriate Technology in Health, which will also help governments and international organizations to implement their own programmes.

Costs for the three-year demonstration programme are estimated at $\$ 12.5 \mathrm{mil}$ lion; a substantial part has already been promised by charitable foundations, and the health programme is "confident" that the remainder will be found.

Tim Beardsley 